This is an author produced version of a paper published in Journal of Helminthology.

This paper has been peer-reviewed and is proof-corrected, but does not include the journal pagination.

Citation for the published paper:

Dreyfuss, G.; Correa, A. C.; Djuikwo-Teukeng, F. F.; Novobilský, A.; Höglund, J.; Pankrác J.; Kašný M.; Vignoles, P.; Hurtrez-Boussès S.; Pointier, J. P.; Rondelaud, D.. (2015) Differences in the compatibility of infection between the liver flukes Fascioloides magna and Fasciola hepatica in a Colombian population of the snail Galba sp.. Journal of Helminthology. Volume: 89, Number: 6, pp 720-726.

http://dx.doi.org/10.1017/S0022149X14000509.

Access to the published version may require journal subscription. Published with permission from: Cambridge University Press.

Epsilon Open Archive http://epsilon.slu.se 
Original article

\title{
Differences in the compatibility of infection between the liver flukes Fascioloides magna and Fasciola hepatica in a Colombian population of the snail Galba sp.
}

\author{
G. Dreyfuss ${ }^{1}$, A.C. Correa $^{2}$, F.F. Djuikwo-Teukeng ${ }^{1,3,}$ A. Novobilský ${ }^{4}$, J. Höglund ${ }^{4}$, \\ J. Pankrác ${ }^{5}$, M. Kašnýy ${ }^{5,6}$, P. Vignoles ${ }^{1}$, S. Hurtrez-Boussès ${ }^{2}$, J.P. Pointier ${ }^{7}$, D. Rondelaud ${ }^{1}$ \\ ${ }^{1}$ INSERM 1094, Faculties of Medicine and Pharmacy, 87025 Limoges, France; \\ ${ }^{2}$ Maladies Infectieuses et Vecteurs: Ecologie, Génétique, Evolution, Contrôle (MIVEGEC), UMR (UM 1-UM 2- \\ CNRS 5290-IRD 224), IRD, BP 64501, 34394 Montpellier 5, France; \\ ${ }^{3}$ Faculty of Health Sciences, Université des Montagnes, BP 208, Banganté, Cameroon; \\ ${ }^{4}$ Department of Biomedical Sciences and Veterinary Public Health, Section for Parasitology, Swedish \\ University of Agricultural Sciences (SLU), 75007 Uppsala, Sweden; \\ ${ }^{5}$ Department of Parasitology, Faculty of Science, Charles University, Vinicna 7, 12844 Prague, Czech Republic; \\ ${ }^{6}$ Department of Botany and Zoology, Faculty of Science, Masaryk University, Kotlarska 2, 61137 Brno, Czech \\ Republic; ${ }^{7}$ USR 3278 CNRS-EPHE, Université, 52 avenue Paul Alduy, 66860 Perpignan, France
}

Running title: Compatibility of Galba sp. with two liver fluke species

* Correspondence: Pr. G. Dreyfuss, address above.

Tel./Fax: 33.5.55.43.58.63. E-mail: gilles.dreyfuss@unilim.fr

Submitted to the Journal of Helminthology,

May 2014 


\begin{abstract}
Experimental infections of Galba sp. (origin, Colombia) with allopatric isolates of Fasciola hepatica from France or Fascioloides magna from Czech Republic were carried out during five successive snail generations to determine if this lymnaeid might sustain complete larval development of either parasite. In snails exposed to $F$. hepatica, 7 of 400 snails harboured several rediae and only 2 snails contained a small number of free cercariae on day 50 post-exposure. In contrast, the intensity of F. magna infection in Galba sp. progressively increased from the F1 to F5 generations. Spontaneous cercarial shedding of F. magna occurred in 7 of 100 Galba sp. belonging to the F5 generation and the number of shed cercariae did not significantly differ from that noted in control Galba truncatula of French origin. Galba sp. from Colombia can be added to the list of potential intermediate hosts for F. magna.
\end{abstract}

Key words: cercaria, experimental infection, Fasciola hepatica, Fascioloides magna, Galba sp., Galba truncatula, redia, snail generation. 


\section{Introduction}

Freshwater snails of the Lymnaeidae family are known to be intermediate hosts for many digenean species. According to Brown (1978) and Mas-Coma et al. (2005), members within this family can sustain larval development of more than 70 different trematodes. As epidemiological studies made on these parasites need the accurate identification of the snail host, several methods using shell morphology and/or the anatomy of the reproductive system have been proposed over the years to classify these lymnaeids (Hubendick, 1951; Burch, 1982).

Shell characters have been extensively, and very often exclusively, used to build the systematics of molluscs. Marine shells are diversified and present a very large set of morphological characters, i.e. protoconch structure, teleoconch ornamentation, radula morphology, etc..., that have proved useful in malacological taxonomy. In freshwater pulmonates, these shell characters are for the most part absent and shell shape only has been used to describe new taxa in the last $19^{\text {th }}$ and $20^{\text {th }}$ centuries and even sometimes in most recent years. As a result of using shell as diagnostic species character, a plethora of names may be found in the literature on freshwater pulmonates, numerous probably being synonyms. The case of the Lymnaeidae family is caricatural with about 1200 described species and several dozens of genera (Hubendick, 1951; Burch, 1982), whereas recent studies suggested that the family contained approximately 100 species (Strong et al., 2008; Jarne et al., 2010).

The classification systems based on morphological characters of shell shape have rapidly generated a controversy because lymnaeids exhibited a great diversity in shell morphology linked to substantial ecophenotypic plasticity (Samadi et al., 2000; Hurtrez-Boussès et al., 2005; Schniebs et al., 2011). It is accepted that anatomical characteristics of the snail's reproductive system are more homogeneous (Pointier et al., 2009; Correa et al., 2011), but only DNA-based analyses, i.e. phylogeny and barcoding, developed from the 2000s could effectively solve this taxonomic problem. As these last analyses allowed to ascribe individuals to one species or another, several new species such as Lymnaea neotropica (Bargues et al., 2007), Galba sp. (Correa et al., 2010, 2011) or Lymnaea schirazensis (Bargues et al., 2011) have been recognized and/or described.

The conchological characteristics of Galba sp. correspond to that of several dozens of taxa reported in North America, presumably the geographic origin of this small-shelled species clade (see Hubendick, 1951; Burch, 1982; Correa et al., 2010; Johnson et al., 2013). This snail was arbitrarily identified by Bargues et al. (2011) as L. schirazensis, a species originally described from Shiraz by Küster in 1862 . However, the original description of L. schirazensis is only based on conchological characters, i.e. three lines in Latin and 16 lines in German (see von den Busch in Küster, 1862), that have proved inadequate to ascribe any sampled lymnaeid to a given species 
(Samadi et al., 2000; Correa et al., 2011). Galba sp. was reported also by Correa et al. $(2010,2011)$ as sufficiently divergent from other Galba species to be considered as a different species. Malacological surveys and subsequent molecular characterization revealed the occurrence of this taxon in the Dominican Republic, Ecuador, Egypt, Iran, Mexico and Peru (as Lymnaea schirazensis: Bargues et al., 2011) as well as in La Reunion Island, Spain and Venezuela (as Galba sp.: Correa et al., 2011). These two studies (Bargues et al., 2011, and Correa et al., 2011) clearly demonstrated that this taxon is an overlooked highly invasive species.

The snail Galba sp. has apparently a worldwide distribution (Correa et al., 2010, 2011; Bargues et al., 2011), which raises the question of whether this snail is able to sustain larval development of different digeneans. Among them, the liver fluke, Fasciola hepatica, is the most known (Torgerson \& Claxton, 1999; Hurtrez-Boussès et al., 2001) and some recent papers have mentioned natural or experimental infection of South American lymnaeids with this parasite (Pointier et al., 2006, 2009; Bargues et al., 2007, 2012a, b; Mera y Sierra et al., 2009). Even if the presence of another digenean, Fascioloides magna, was not still reported in South America, a recent paper (Sanabria et al., 2013) reported successful experimental infections of Lymnaea neotropica and L. viatrix var. ventricosa with this parasite. In view of the above results, the following two questions arose: might a Colombian population of Galba sp. sustain complete larval development of F. hepatica with cercarial shedding? Was also this population a potential intermediate host for F. magna? To answer these questions, five successive generations of this snail were experimentally infected with $F$. hepatica or F. magna to determine if this species is a potential intermediate host for these digeneans.

\section{Materials and methods}

Collection of snails and fluke eggs

The population of Galba sp. was collected from a farm at Finca el Ayer (6 $\left.28^{\prime} 9^{\prime \prime} \mathrm{N}, 75^{\circ} 22^{\prime} 27^{\prime \prime} \mathrm{W}\right)$ at altitude of 2,248 m near Medellin, department of Antioquia, Colombia. The population as Galba sp. was identified as

Galba sp. via the study of rDNA (18S, ITS-1, ITS-2) and mtDNA cox1 because the sequences obtained were similar to those deposited in GenBank by Bargues et al. (2011) and Correa et al. (2011). A total of 28 adult snails were collected from this farm in May 2012 and were raised in 14-cm Petri dishes at $20^{\circ} \mathrm{C}$ under laboratory conditions according to Rondelaud et al. (2007). Egg masses laid by these parent snails were collected and placed into other 14-cm Petri dishes containing oxygenated spring water and finely powdered lettuce as food for newly hatched individuals. Those, which attained $4 \mathrm{~mm}$ in shell height, were considered as the F1 generation and were used for experiments. The protocol was similar for the F2, F3, F4 and F5 snail generations (see below). A 
total of 700 snails, measuring $4 \pm 0.1 \mathrm{~mm}$ in height and belonging to the F1, F2, F3, F4 and F5 generations were used for experiments (Table 1). To compare the characteristics of F. magna infection in Galba sp. with those found in a common intermediate host of this parasite, a wild population of Galba truncatula was selected. These snails colonized a road ditch at Chézeau Chrétien $\left(46^{\circ} 40^{\prime} 27^{\prime \prime} \mathrm{N}, 1^{\circ} 21^{\prime} 21^{\prime \prime} \mathrm{E}\right)$, commune of Chitray, department of Indre, central France. One hundred snails (shell height, $4 \mathrm{~mm}$ ), belonging to the overwintering generation, were collected from this population and acclimatized for 24 hours to laboratory temperature before being directly exposed to F. magna miracidia (Table 1).

Eggs of $F$. hepatica came from the gall bladders of naturally infected cattle at the slaughterhouse of Limoges, department of Haute Vienne, central France. Those of F. magna were collected from adult flukes recovered from the livers of naturally infected red deer (Cervus elaphus) hunted near the Mirošov village, Central Bohemia, Czech Republic. These egg isolates were washed several times with spring water and were incubated for 20 days at $20^{\circ} \mathrm{C}$ in the dark (Ollerenshaw, 1971).

Experiment 1: Galba sp. as a potential host for Fasciola hepatica \& Fascioloides magna

The susceptibility of Galba sp. to F. hepatica or F. magna miracidia was studied in five successive snail generations via an experimental protocol already used by Sanabria et al. (2012) for F. hepatica and Vignoles et al. (2014) for F. magna. F2 snails originated from eggs laid by parasite-exposed individuals of the F1 generation between weeks 2 and 5 post-exposure. A similar protocol was used for the F3, F4 and F5 generations. This protocol was chosen in order that these descendants have a first (F2) or multiple contacts (F3, F4 or F5 generations) with the parasite through their parents.

The aim of the first experiment was to determine the aptitude of Galba sp. as a snail host for F. hepatica or F. magna. Five groups of Galba sp. with a variable number of snails per group were constituted for infections with F. hepatica (Table 1). In addition, four other groups of 50 snails each were constituted for the F1, F2, F3 or F4 generations of Galba sp. and were exposed to F. magna miracidia (Table 1). Each snail was subjected to two miracidia of F. hepatica or a single miracidium of $F$. magna for four hours at $20^{\circ} \mathrm{C}$ in $3.5 \mathrm{~mL}$ spring water. The choice of this sequence in the number of miracidia per snail was based on our experience in the production of trematode infective stages (Vignoles et al., 2006; Rondelaud et al., 2014a). Snails were then raised for 50 days in groups of ten individuals in 14-cm Petri dishes with $60 \mathrm{~mL}$ spring water per dish according to the method by Rondelaud et al. (2007). Snail food consisted of dried leaves of pesticide-free lettuce and dead Molinia caerulea leaves, while stems of live Fontinalis sp. ensured oxygenation of the water layer. Dissolved calcium in spring 
water was $35 \mathrm{mg} / \mathrm{L}$. Petri dishes were placed in an air-conditioned room under the following conditions: a temperature of $20^{\circ} \mathrm{C}$, natural photoperiod of ten hours light. On day 50 post-exposure, surviving snails were dissected under a stereomicroscope to detect the presence of larval forms of $F$. hepatica or F. magna within their bodies and determine the most developed stage: immature rediae, cercariae-containing rediae, or free cercariae. Infected snails were counted taking into account snail generation and each developmental stage of larval development.

Experiment 2: comparison of Fascioloides magna infection in Galba sp and G. truncatula

As numerous free cercariae exceeding 20 per snail were only noted in the $\mathrm{F} 3$ and $\mathrm{F} 4$ generations of $F$. magna-infected Galba sp. (Table 1), a second experiment was carried out to determine the characteristics of these F. magna infections in snails belonging to the F5 generation and compare them with those which occurred in G. truncatula. One hundred Galba sp. and one hundred G. truncatula were used (Table 2). Snail exposure to miracidia and maintenance during the first 30 days were similar to those in the first experiment. On day 30 , each surviving snail was isolated in a 35-mm Petri dish with pieces of dead grass, lettuce and spring moss, and placed at $20^{\circ} \mathrm{C}$. Spring water and food were changed, if necessary, every day until snail death. When the first cercarial shedding occurred, surviving snails were subjected to a thermal shock every three days by placing their Petri dishes at $10^{\circ} \mathrm{C}-13^{\circ} \mathrm{C}$ for 3 hours to stimulate cercarial exit (Sanabria et al., 2012). After their emergence, cercariae were counted and removed from Petri dishes. At the death of each infected snail, its shell was measured using callipers. Cadavers of non-shedding snails were routinely dissected under a stereomicroscope to count free rediae and free cercariae.

\section{Data analysis}

The first two parameters were snail survival on day 30 post-exposure and the prevalence of $F$. hepatica or $F$. magna infection calculated in relation to the number of snails surviving on day 30 . In the first experiment, prevalence took into account the numbers of snails with immature rediae only, cercariae-containing rediae, or with free cercariae. In the second experiment, cercariae-shedding and non-shedding snails were used for prevalence calculation. For each parameter, the differences were analyzed using a $\chi^{2}$ test. In the second experiment, shell growth of infected snails during the experiment, the length of pre-patent and patent periods, and the total number of shed cercariae were also calculated. Free rediae and free cercariae counted in the cadavers of non-shedding snails were also considered. Individual values recorded for these last six measurements 
were averaged and their standard deviations were established for each snail group. One-way analysis of variance (ANOVA) was used to establish levels of statistical significance. The different analyses were performed using Statview 5.0 software (SAS Institute Inc., Cary, NC, USA).

\section{Results}

Experiment 1: Galba sp. as a potential host for Fasciola hepatica \& Fascioloides magna

Survival rates of $F$. hepatica-exposed Galba sp. on day 30 post-exposire ranged from $18.6 \%$ to $34.0 \%$ although no significant difference between these rates was found (Table 1). Low prevalences of $<16 \%$ were noted in the F2-F5 generations of snails, without significant difference. However, larval development of F. hepatica was not complete in these snails because two individuals only harboured immature rediae, three several rediae containing a few differentiating cercariae and the last two others a few rediae and several free cercariae within their bodies. The number of free rediae ranged from three to six, while the numbers of free cercariae in the two snails of the F2 and F3 generations were 7 and 14, respectively (data not shown). In Galba sp. exposed to F. magna, the survival rate on day 30 was not significantly different from the F1 to F4 generations (Table 1). A similar finding was also noted for prevalence of $F$. magna infection through each snail generation. In spite of this, the intensity of snail infection increased with increasing snail generation, ranging from two snails harbouring immature rediae in the F1 to nine snails in the F4 generation. In this last generation, 5 of 9 individuals contained free cercariae.

Experiment 2: comparison of Fascioloides magna infection in Galba sp and G. truncatula Survival of Galba sp. on day 30 post-exposure was significantly lower than for G. truncatula (Table 2). Similar findings were also noted for prevalence of F. magna infection and shell growth of infected snails during the experiment. Comparison of the pre-patent periods, patent periods or the numbers of shed cercariae for both snail species revealed no significant differences. Spontaneous cercarial shedding occurred in 4 of 7 Galba sp., with one, two or three shedding waves for 1, 2 and 4 snails, respectively (data not shown). In G. truncatula, cercarial shedding occurred always after a thermal shock and one, two, three or four shedding waves were noted for 9, 7, 9 and 14 snails, respectively (data not shown). In non-shedding Galba sp., the number of free rediae was significantly lower than that noted in non-shedding G. truncatula, while the number of free cercariae did not significantly differ from each other. 


\section{Discussion}

Low survival rates on day 30 post-exposure were noted in the ten groups of Galba sp., whatever the digenean species (Tables 1 and 2). These findings may be mainly explained by the negative effect of the parasite species used on the life span of the snail. However, another hypothesis, based on inadequate conditions for Galba sp. breeding in the laboratory, cannot be completely excluded. In the field, Galba sp. seems to be a more amphibious snail than G. truncatula because adult individuals of Galba sp. were often observed on the emerged soil up to a 2-m distance from the waterside.

In spite of five successive generations of Galba sp. exposed to F. hepatica miracidia, only a few snails contained several rediae with/without free cercariae in their body on day 50 post-exposure. This finding cannot be explained by a low infectivity of French $F$. hepatica miracidia used in the present study because these larvae, originating mainly from local triclabendazole-treated cattle, showed a strong infectivity since the 2000s (Dreyfuss et al., 2007) and experimental infections of local G. truncatula resulted in $72.1 \%$ prevalence with 44 cercariae-shedding snails out of 61 individuals surviving on day 30 and in a mean production of 222.1 shed cercariae (Sanabria et al., 2012). It cannot also be explained by a low development of parasite larval forms over time because a few free cercariae were noted in the body of two dissected Galba sp. on day 50. Under these conditions, it is necessary to admit a problem of compatibility between Galba sp. and the French isolate of $F$. hepatica. This finding was surprising because our snails originated from the department of Antioquia (Colombia) and this district was known to be an at-risk district for human and animal fasciolosis (Mas-Coma et al., 2009; Correa et al., 2011; Valencia-López et al., 2012). However, Galba sp. was not completely refractory to the parasite because of development of F. hepatica larval forms in several experienced snails (Table 1). A similar result was obtained for $L$. schirazensis using an isolate of $F$. hepatica from Poland and a snail strain from Spain (Bargues et al., 2011). To explain the problem of compatibility between Galba sp. and the parasite, three hypotheses may be proposed. First, the compatibility between Galba sp. and F. hepatica might need strong selection process among numerous successive generations of snails, as that suggested by Boray (1969) in his review on fasciolosis for several lymnaeid species. Secondly, a snail co-infection with $F$. hepatica and another

digenean such as a paramphistomid might be necessary to induce and favour larval development of $F$. hepatica, as demonstrated by Southgate et al. (1989) in the model Bulinus globosus-Schistosoma bovis and Abrous et al. $(1998,1999)$ in the model Omphiscola glabra-F. hepatica. Thirdly, variation in compatibility between strains of snails and geographic isolates of parasites may occur. Such a strong variation has already been shown in Cuba using different combinations of F. hepatica geographic isolates and populations of Galba cubensis and 
Pseudosuccinea columella from different localities (Vázquez et al., 2014). In this study, infection rates of G. cubensis may vary from 0 to $100 \%$ for the Sagua and Arroz isolates of $F$. hepatica, respectively.

After five generations with selection of infected snails, we obtained complete larval development of $F$. magna under experimental conditions, even if the infection of these five successive snail generations was necessary to have a progressive increase in the intensity of $F$. magna infection. This finding suggests a progressive and rapid adaptation of this snail population to the parasite through several successive snail generations. The present results do not bring any substantial element in favour of a particular susceptibility of Central and South American Galba species to F. magna. In our opinion, this successful infection of the Colombian Galba sp. would only result from the sole infectivity of the miracidium. An argument supporting this hypothesis is the wide range of intermediate hosts reported in North America (Dunkel et al., 1996) and Europe (Huňová et al., 2012; Novobilský et al., 2012; Rondelaud et al., 2014b) for this digenean.

Results for the F5 generation of Galba sp. and F. magna are inconclusive. Even if snail survival on day 30 and prevalence of F. magna infection were significantly lower than those noted for G. truncatula, the pre-patent period and the number of shed cercariae did not significantly differ between Galba sp. and G. truncatula, whereas the shell growth of Galba sp. during the experiment was lower: $1.7 \mathrm{~mm}$ instead of $3.5 \mathrm{~mm}$ for $G$. truncatula (Table 2). Moreover, spontaneous cercarial shedding of F. magna occurred in 4 of 7 snails, whereas this process was scarce for G. truncatula under laboratory conditions without thermal shock (Erhardová-Kotrlá, 1971; Vignoles et al., 2006). In spite of differences in snail survival and prevalence of infection, Galba sp. seems to be a suitable intermediate host like G. truncatula. No reliable explanation can be given at the present time to explain the performances of this Colombian population of Galba sp. in larval development of F. magna and additional studies are still necessary.to verify if other populations of this taxon can also sustain complete larval development of this digenean with the same performances.

In conclusion, Galba sp. can be added to the list of potential intermediate hosts of F. magna as this species was experimentally infected. Although the susceptibility of this species to infection with French miracidia of $F$. hepatica was very low, we noted that it was not totally refractory. Additional studies on other populations of Galba sp. are still necessary to determine if the low susceptibility to French F. hepatica and the good aptitude for larval development of F. magna only concern the Colombian population used in the present study, or if they can be generalized to other haplotypes of this species living in the Old and New Worlds (Correa et al., 2011).

\section{Acknowledgements}


This study was supported by the Charles University in Prague (UNCE 204017, PRVOUK P41and SVV 267210/2013) and Masaryk University Brno (MUNI/A/0888/2013 and CZ.1.07/2.4.00/31.01.55).

\section{References}

Abrous, M., Rondelaud, D., Dreyfuss, G. \& Cabaret, J. (1998) Unusual transmission of the liver fluke, Fasciola hepatica, by Lymnaea glabra or Planorbis leucostoma in France. Journal of Parasitology 84, 1257-1259.

Abrous, M., Rondelaud, D., Dreyfuss, G. \& Cabaret, J. (1999) Infection of Lymnaea truncatula and Lymnaea glabra by Fasciola hepatica and Paramphistomum daubneyi in farms of central France. Veterinary Research 30, 113-118.

Bargues, M.D., Artigas, P., Mera y Sierra, R.L., Pointier, J.P. \& Mas-Coma, S. (2007) Characterisation of Lymnaea cubensis, L. viatrix and L. neotropica n. sp., the main vector of Fasciola hepatica in Latin America, by analysis of their ribosomal and mitochondrial DNA. Annals of Tropical Medicine and Parasitology 101, 621-641.

Bargues, M.D., Artigas, P., Khoubbane, M., Flores, R., Glöer, P., Rojas-Garcia, R., Ashrafi, K., Falkner, G. \& Mas-Coma, S. (2011) Lymnaea schirazensis, an overlooked snail distorting fascioliasis data: genotype, phenotype, ecology, worldwide spread, susceptibility, applicability. PloS One 6, e24567.

Bargues, M.D., Artigas, P., Khoubbane, M., Ortiz, P., Naquira, C. \& Mas-Coma, S. (2012a) Molecular characteristics of Galba truncatula, Lymnaea neotropica and Lymnaea schirazensis from Cajamarca, Peru and their potential role in transmission of human and animal fascioliasis. Parasites and Vectors 15, 174.

Bargues, M.D., Mera y Sierra, R.L., Artigas, P. \& Mas-Coma, S. (2012b) DNA multigene sequencing of topotypic specimens of the fascioliasis vector Lymnaea diaphana and phylogenetic analysis of the genus Pectinidens (Gastropoda). Memórias do Instituto Oswaldo Cruz 107, 111-124.

Boray, J.C. (1969) Experimental fascioliasis in Australia. Advances in Parasitology 7, 95-210.

Brown, D.S. (1978) Pulmonate molluscs as intermediate hosts for digenetic trematodes. Pp. 287-333. In Fretter, V. \& Peake, J. (Eds), Pulmonates, Vol. 2A. Systematics, evolution and ecology. London, Academic Press.

Burch, J.B. (1982) North American freshwater snails. Transactions of the POETS Society 1, 217-365.

Correa, A.C., Escobar, J.S., Durand, P., Renaud, F., David, P., Jarne, P., Pointier, J.P. \& HurtrezBoussès, S. (2010) Bridging gaps in the molecular phylogeny of the Lymnaeidae (Gastropoda: Pulmonata), vectors of fascioliasis. BMC Evolutionary Biology 10, 381. 
Correa, A.C., Escobar, J.S., Noya, O., Velásquez, L.E., González-Ramírez, C., Hurtrez-Boussès, S. \&

Pointier, J.P. (2011) Morphological and molecular characterization of Neotropic Lymnaeidae (Gastropoda: Lymnaeoidea), vectors of fasciolosis. Infection, Genetics and Evolution 11, 1978-1988.

Dreyfuss, G., Vignoles, P. \& Rondelaud, D. (2007) Fasciola hepatica: the infectivity of cattle-origin miracidia had increased over the past years in central France. Parasitology Research, 101, 1157-1160.

Dunkel, A.M., Rognlie, M.C., Johnson, G.R. \& Knapp, S.E. (1996) Distribution of potential intermediate hosts for Fasciola hepatica and Fascioloides magna in Montana, USA. Veterinary Parasitology 62, 63-70.

Erhardová-Kotrlá, B. (1971) The occurrence of Fascioloides magna (Bassi, 1875) in Czechoslovakia. Prague, Academia.

Hubendick, B. (1951) Recent Lymnaeidae: their variation, morphology, taxonomy, nomenclature and distribution. Kungliga Svenska Vetenskapsakademiens Handlingar 3, 1-223.

Huňová, K., Kašný, M., Hampl, V., Leontovyč, R., Kuběna, A., Mikeš, L. \& Horák, P. (2012) Radix spp.: identification of trematode intermediate hosts in the Czech Republic. Acta Parasitologica 57, 273-284.

Hurtrez-Boussès, S., Meunier, C., Durand, P. \& Renaud, F. (2001) Dynamics of host-parasite interactions: the example of population biology of the liver fluke (Fasciola hepatica). Microbes and Infection 3, 841849.

Hurtrez-Boussès, S., Pendion, A., Bernabé, C., Durand, P., Rondelaud, D., Durand, C., Meunier, C., Hurtrez, J.E. \& Renaud, F. (2005) Comparison between shell morphology and genetic diversity in two sympatric lymnaeid snails, vectors of fascioliasis. Canadian Journal of Zoology 83, 1643-1648.

Jarne, P., David, P., Pointier, J.P. \& Koene, J.M. (2010) Basommatophoran gastropods. Pp. 173-186. In Cordoba-Aguilar, A. \& Leonard, J.L. (Eds.), The evolution of primary sexual characters in animals. London, Academic Press.

Johnson, P.D., Bogan, A.E., Brown, K.M., Burkhead, N.M., Cordeiro, J.R., Garner, J.T., Hartfield, P.D., Lepitzki, D.A.W., Mackie, G.L., Pip, E., Tarpley, T.A., Tiemann, J.S., Whelan, N.V. \& Strong, E.E. (2013) Conservation status of freshwater gastropods of Canada and the United States. Fisheries, 38 (6), $247-282$.

Küster, H.C. (1862) Limnaeus schirazensis von dem Busch. Pp. 53. In Martini, F.H.W. \& Chemnitz, J.H. (Eds), Systematisches Conchylien-Cabinet, $2^{\text {nd }}$ edit. Nürnberg 1, Bauer \& Raspe, $17 \mathrm{~b}$.

Mas-Coma, S., Bargues, M.D. \& Valero, M.A. (2005) Fascioliasis and other plant-borne trematode zoonoses. International Journal for Parasitology 35, 1255-1278. 
Mas-Coma, S., Valero, M.A. \& Bargues, M.D. (2009) Fasciola, lymnaeids and human fascioliasis, with a global overview on disease transmission, epidemiology, evolutionary genetics, molecular epidemiology and control. Advances in Parasitology 69, 44-146.

Mera y Sierra, R., Artigas, P., Cuervo, P., Deis, E., Sidoti, L., Mas-Coma, S. \& Bargues, M.D. (2009) Fascioliasis transmission by Lymnaea neotropica confirmed by nuclear rDNA and mtDNA sequencing in Argentina. Veterinary Parasitology 166, 73-79.

Novobilský, A., Kašný, M., Pankrác, J., Rondelaud, D., Engström, A. \& Höglund, J. (2012) Lymnaea fuscus (Pfeiffer 1821) as a potential intermediate host of Fascioloides magna in Europe. Experimental Parasitology 132, 282-286.

Ollerenshaw, C.B. (1971) Some observations on the epidemiology of fascioliasis in relation to the timing of molluscicide applications in the control of the disease. The Veterinary Record 88, 152-164.

Pointier, J.P., Cazzaniga, N.J., González-Salas, C., Gutiérrez, A., Arenas, J.A., Bargues, M.D. \& MasComa, S. (2006) Anatomical studies of sibling species within Neotropical lymnaeids, snail intermediate hosts of fascioliasis. Memórias do Instituto Oswaldo Cruz 101, 431-435.

Pointier, J.P., Noya, O., Alarcón de Noya, B. \&Théron, A. (2009) Distribution of Lymnaeidae (Mollusca: Pulmonata), intermediate hosts of Fasciola hepatica in Venezuela. Memórias do Instituto Oswaldo Cruz 104, 790-796.

Rondelaud, D., Fousi, M., Vignoles, P., Moncef, M. \& Dreyfuss, G. (2007) Optimization of metacercarial production for three digenean species by the use of Petri dishes for raising lettuce-fed Galba truncatula. Parasitology Research 100, 861-865.

Rondelaud, D., Mouzet, R., Vignoles, P., Dreyfuss, G. \& Cabaret, J. (2014a) The production of trematode infective stages for mammalians by the snail host Galba truncatula. Journal of Helminthology 88, $105-111$.

Rondelaud, D., Novobilský, A., Höglund, J., Kašný, M., Pankrác, J., Vignoles, P. \& Dreyfuss, G. (2014b) Growth rate of the intermediate snail host Galba truncatula influences redial development of the trematode Fascioloides magna. Journal of Helminthology in press (Doi: 10.1017/S0022149X13000370).

Samadi, S., Roumégoux, A., Bargues, M.D., Mas-Coma, S. \& Pointier, J.P. (2000) Morphological studies of lymnaeid snails from the human fascioliasis endemic zone of Bolivia. Journal of Molluscan Studies, 66, 31-44. 
Sanabria, R., Mouzet, R., Courtioux, B., Vignoles, P., Rondelaud, D., Dreyfuss, G., Cabaret, J. \& Romero, J. (2012) Intermediate snail hosts of French Fasciola hepatica: Lymnaea neotropica and Lymnaea viatrix are better hosts than local Galba truncatula. Parasitology Research 111, 2011-2016.

Sanabria, R., Mouzet, R., Pankrác, J., Djuikwo Teukeng, F.F., Courtioux, N., Novobilský, A., Höglund, J., Kašný, M., Vignoles, P., Dreyfuss, G., Rondelaud, D. \& Romero, J. (2013) Lymnaea neotropica and Lymnaea viatrix, potential intermediate hosts for Fascioloides magna. Journal of Helminthology, 87, 494500.

Schniebs, K., Glöer, P., Vinarski, M.V. \& Hundsdoerfer, A.K. (2011) Intraspecific morphological and generic diversity in Radix balthica (Linnaeus 1758) (Gastropoda: Basommatophora: Lymnaeidae) with morphological comparison to other European Radix species. Journal of Conchology 40, 657-678.

Southgate, V.R., Brown, D.S., Warlow, R., Knowles, R.J. \& Jones, A. (1989) The influence of Calicophoron microbothrium on the susceptibility of Bulinus tropicus to Schistosoma bovis. Parasitology Research $\mathbf{7 5}$, $381-391$.

Strong, E.E., Gargominy, O., Ponder, W.F. \& Bouchet, P. (2008) Global diversity of gastropods (Gastropoda; Mollusca) in freshwater. Hydrobiologia 595, 149-166.

Torgerson, P. \& Claxton, J. (1999) Epidemiology and control. Pp. 113-149. In Dalton, J.P. (Ed.), Fasciolosis. Oxon, CABI Publishing.

Valencia-López, N., Malone, J.B., Gómez Carmona, C. \& Velásquez, L.E. (2012) Climate-based risk models for Fasciola hepatica in Colombia. Geospatial Health 6, 573-685.

Vázquez, A.A., Sánchez, J., Pointier, J.P., Théron, A. \& Hurtrez-Boussès, S. (2014) Fasciola hepatica in Cuba: compatibility of different isolates with two intermediate snail hosts, Galba cubensis and Pseudosuccinea columella. Journal of Helminthology, in press (Doi: 10.1017/S0022149X13000382).

Vignoles, P., Novobilský, A., Rondelaud, D., Bellet, V., Treuil, P., Koudela, B. \& Dreyfuss, G. (2006) Cercarial production of Fascioloides magna in the snail Galba truncatula (Gastropoda: Lymnaeidae). Parasitology Research 98, 462-467.

Vignoles, P., Novobilský, A., Höglund, J., Kašný, M., Pankrác, J., Dreyfuss, G., Pointier, J.P. \& Rondelaud, R. (2014) Lymnaea cubensis (Pfeiffer, 1839), an experimental intermediate host for Fascioloides magna. Folia Parasitologica 61, 185-188. 


\section{Table 1}

Characteristics of infections in several generations of Galba sp. exposed to Fasciola hepatica and Fascioloides magna on day 50 (first experiment). $\mathrm{N}$ = number of exposed snails on day 1.

\begin{tabular}{|c|c|c|c|c|c|c|}
\hline \multirow{2}{*}{$\begin{array}{l}\text { Fasciolid } \\
\text { species and } \\
\text { snail generation }\end{array}$} & \multirow[t]{2}{*}{$\mathrm{N}$} & \multirow{2}{*}{$\begin{array}{l}\text { Snail survival } \\
(\%) \text { on day } 30 \\
\text { post-exposure }\end{array}$} & \multicolumn{3}{|c|}{ No. of infected snails with } & \multirow{2}{*}{$\begin{array}{l}\text { Overall } \\
\text { prevalence } \\
(\%)\end{array}$} \\
\hline & & & $\begin{array}{l}\text { Immature } \\
\text { rediae }\end{array}$ & $\begin{array}{l}\text { Cercariae- } \\
\text { containing } \\
\text { rediae }\end{array}$ & $\begin{array}{l}\text { Free } \\
\text { cercariae }\end{array}$ & \\
\hline \multicolumn{7}{|l|}{ F. hepatica } \\
\hline F1 & 50 & 26.0 & & & & 0 \\
\hline $\mathrm{F} 2$ & 100 & 20.0 & 1 & & 1 & 10.0 \\
\hline F3 & 150 & 18.6 & & 1 & 1 & 7.1 \\
\hline $\mathrm{F} 4$ & 50 & 26.0 & 1 & 1 & & 15.3 \\
\hline F5 & 50 & 34.0 & & 1 & & 5.8 \\
\hline \multicolumn{7}{|l|}{ F. magna } \\
\hline $\mathrm{F} 1$ & 50 & 22.0 & 2 & & & 18.1 \\
\hline F2 & 50 & 30.0 & 1 & 2 & & 20.0 \\
\hline F3 & 50 & 34.0 & 1 & 3 & 2 & 35.2 \\
\hline $\mathrm{F} 4$ & 50 & 46.0 & 2 & 2 & 5 & 39.1 \\
\hline
\end{tabular}


Table 2

Characteristics of Fascioloides magna infection in the F5 generation of Galba sp. and in Galba truncatula

subjected to single-miracidium infections and reared at $20^{\circ} \mathrm{C}$ (second experiment). Mean values of six

parameters are given \pm standard deviations and levels of significance include $* \mathrm{p}<0.05,{ }^{* *} \mathrm{p}<0.01,{ }^{* * *} \mathrm{p}<0.001$.

\begin{tabular}{lll}
\hline Population & Galba sp., F5 & G. truncatula \\
\hline Snail survival (\%): & & \\
- Day 1 & 100 & 100 \\
- Day 30 & 48.0 & $71.0^{* *}$ \\
Number of snails: & & \\
- cercariae-shedding snails & 7 & 39 \\
- non-shedding snails & 4 & 15 \\
Prevalence of F. magna infection (\%) & 22.9 & $76.0^{* * *}$ \\
Growth of cercariae-shedding and & $1.7 \pm 0.5$ & $3.5 \pm 0.6^{* * *}$ \\
non-shedding snails (mm) & & \\
Pre-patent period (days) & $67.4 \pm 9.3$ & $69.8 \pm 5.7$ \\
Patent period (days) & $16.2 \pm 3.7$ & $22.5 \pm 5.8$ \\
Number of shed cercariae & $96.3 \pm 27.4$ & $119.4 \pm 33.1$ \\
Cadavers of non-shedding snails: & & \\
- Free rediae & $24.3 \pm 5.7$ & $34.8 \pm 7.5^{*}$ \\
- Free cercariae & $157.8 \pm 34.7$ & $196.0 \pm 41.1$ \\
\hline
\end{tabular}

